\title{
ENGINEERING APPLICATION OF WASTE TURNING TOOLS TO SUPPORT WASTE MANAGEMENT IN CAMPUS 7 HEALTH POLYTECHNIC OF MINISTRY OF HEALTH SEMARANG
}

\author{
Asep Tata Gunawan ${ }^{1)}$, Yulianto $^{1)}$, Bahri $^{1)}$ \\ ${ }^{1)}$ Environmental Health Department, Health Polytechnicof Ministry of Health Semarang, Indonesia \\ Corresponndence email : aseptatagunawan@yahoo.co.id
}

\begin{abstract}
Introduction: The government of banyumas district by decree number: 660 . $7776 / 2018$ concerning the management of the waste in banyumas district, in which the President's decree strongly recommends the closing of the TPA on January 2, 2019 and urges the management of waste through non-governmental groups (KSM) in trash management $3 \mathrm{r}$ (main, reuse and recycling). The application of $3 \mathrm{r}$ activities in communities is still hampered largely by the lack of awareness of people sorting waste. The world health ministry of semarang, which has an open land of 2.3 ha (2.3 ha), has an average of $4 \mathrm{~m} 3 /$ week organic waste. Thus selecting a comprehensive waste management by using a 10-panted run way method, so each week it is used to invert waste from tub one to tub the next. Based on the above description, the formula of the problem in this study is knowing the effectiveness of the waste turning engineering tools in supporting the waste processing process. Methods: Research and Development is a research method that uses to obtain or develop products and test the effectiveness of these products. The turning tool is designed to compare the effectiveness of the waste turning process before and after using the tool. This research was conducted at a waste processing place (composter) at Campus 7 Poltekkes Kemenkes Semarang. The population in this study were all of the campus residents' solid waste generation. The sample of this study was waste in each tub (from tub 1 to 10) compost processing volume of 0.5-4 $\mathrm{m} 3$ / week. This study used tables analysis and the average value calculated from the results of sieving the waste. Research and discussion: The design and assembly of a waste turning tool is appropriate and can support the composting process of waste at Campus 7 Purwokerto, Health polytechnic of Ministry of Health Semarang. The volume of waste in basins 1 to 10 is on average around $0.5-4 \mathrm{~m} 3$ / week, in each tub per week there is a decrease in waste by an average of about $8-9 \%$, so that starting from basin 1 with a volume of waste $4 \mathrm{~m} 3$ / week decreasing in the basin 10 to 0.5 $\mathrm{m} 3$ / week. The comparison of manual waste reversal using a machine is as follows: Turning over manual waste takes about 5-7.5 minutes per basin with 4 workers, so it takes 50-75 minutes to reverse 10 basins. Turning the trash with a machine takes about 45-50 seconds with 2 workers, so it takes 7.5-8.3 minutes to reverse 10 basins. Conclusion: A waste turning tool has been proven effective to assist and facilitate the process of waste reversal for the decomposition process in the composting basin at the campus 7 composting place.
\end{abstract}

Keywords: Sanitation Facility Engineering, Waste Processing, Composting, Waste Turnin 


\section{Introduction}

Waste is an item that is produced from the activities of humans and other living things that are no longer used. Waste will become an environmental problem if it is not managed properly. Various types of waste generated from human activities in the form of organic and inorganic waste. Each of these types of waste needs proper management so as not to cause environmental problems (Marwati, 2013).

Waste is a source of disease, either directly or indirectly. Directly, waste is a place for various parasites, bacteria and pathogens to grow; while indirectly waste is a nest for various vectors (disease carriers) such as mice, cockroaches, flies and mosquitoes. Rotting waste, as well as cans, bottles, plastics, is a hotbed of pathogens and disease vectors. Various diseases that can arise due to poorly managed waste are diarrhea, dysentery, worms, malaria, elephantiasis and dengue fever. These diseases are a threat to humans, which can cause death. (Imran SL Tobasing, 2005).

Nowdays, waste is a national issue that has not had an optimum solution yet tends to be a constant problem every year. As a result of the lack of integrated policy or program management and lack of support and participation in both the business and the public.

During its development, it turns out that the waste problem in Indonesia is becoming more complex and widespread, especially related to the issue of marine waste pollution. The results of Jambeck's research, Jena R, et al, (2015) state that the potential for plastic waste in Indonesia's oceans reaches 187.2 million tons / year. With the results of this study, Indonesia is the second largest country that contributes waste after China, followed by the Philippines, Vietnam and Sri Lanka. According to Greenation Research, a nongovernmental organization that has been following the issue of solid waste for 10 years, one Indonesian produces 700 plastic bags per year (Kementerian Pekerjaan Umum dan Perumahan Rakyat, 2016).

Sources of waste generation can come from a variety of places, such as households, offices, trade, industry, construction waste, roads, fisheries / livestock and mining. And the waste generated varies based on where it was generated. For waste handling that has been commonly carried out is direct disposal to the final dumping site (TPA) by open dumping.

Campus 7 Health Polytechnic of the Ministry of Health Semarang, is an educational institution that is integrated with a canteen, housing for lecturers and has open land which reaches 2.3 ha, where organic waste is generated on average 4 $\mathrm{m} 3$ / week and inorganic waste averages
$0.85 \mathrm{~m} 3 /$ week with plastic predominance (GELISH, 2019). To overcome the accumulation of waste, it is necessary to optimize waste processing. Dispose of waste in the usual way by simply throwing the waste in a temporary shelter (TPS) which is then disposed of in final disposal (TPA). This is still considered ineffective in overcoming the existing problems, by taking into account the regent's circular number: 660.1 / 7776/2018, in the circular letter the regent explicitly instructs the closure of the existing landfill starting January 2, 2019 and urges waste management through Community SelfHelp Groups KSM) in 3R waste management. Campus 7 as an educational institution in which there is a Department of Environmental Health and has qualified human resources (HR) in the field of waste processing has pioneered a composter pilot unit with the run way method which is arranged in 10 basins. Efforts to handle organic waste have been realized in the form of processing products in the form of organic compost. Along with composting activities, activity evaluation activities are carried out. The results of the evaluation are important notes in the composting process.

Campus 7 as an educational institution in which there is a Department of Environmental Health and has qualified human resources (HR) in the field of waste processing has pioneered a composter pilot unit with the run way method which is arranged in 10 basins. Efforts to handle organic waste have been realized in the form of processing products in the form of organic compost. Along with composting activities, activity evaluation activities are carried out. The results of the evaluation show important notes on the composting process carried out, such as the process of turning over too much waste, transferring waste to many composting basins, complaints of pungent odors and the risk of being punctured from can / glass waste. All of these conditions were caused by activities being carried out manually by cleaning personnel.

\section{Material and Method}

Research and Development is a research method that uses to obtain or develop products and test the effectiveness of these products This research was conducted at a waste processing site (composter) at Campus 7 Poltekkes Kemenkes Semarang. The population in this study were all of the campus residents' solid waste generation. The sample of this study was garbage in each tub (from tub 1 to 10) compost processing volume of 0.5-4 $\mathrm{m} 3$ / week. The data analysis used in this ${ }^{H} .172$ 


\section{BULLTIN KESLIN GMAS}

Teritets pertama kali April 1982 Buletin Kesehatan Lingkungan Masyarakat

research is table analysis and the average value calculated from the results of sieving the waste.

\section{Result and Discussion}

The trash turner assembly is as follows:

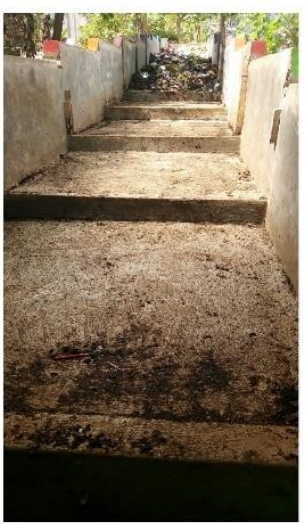

Number of worker

Average Time

The volume ofthe tub

Mass

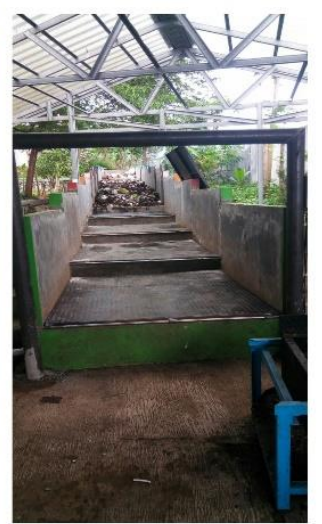

The tool
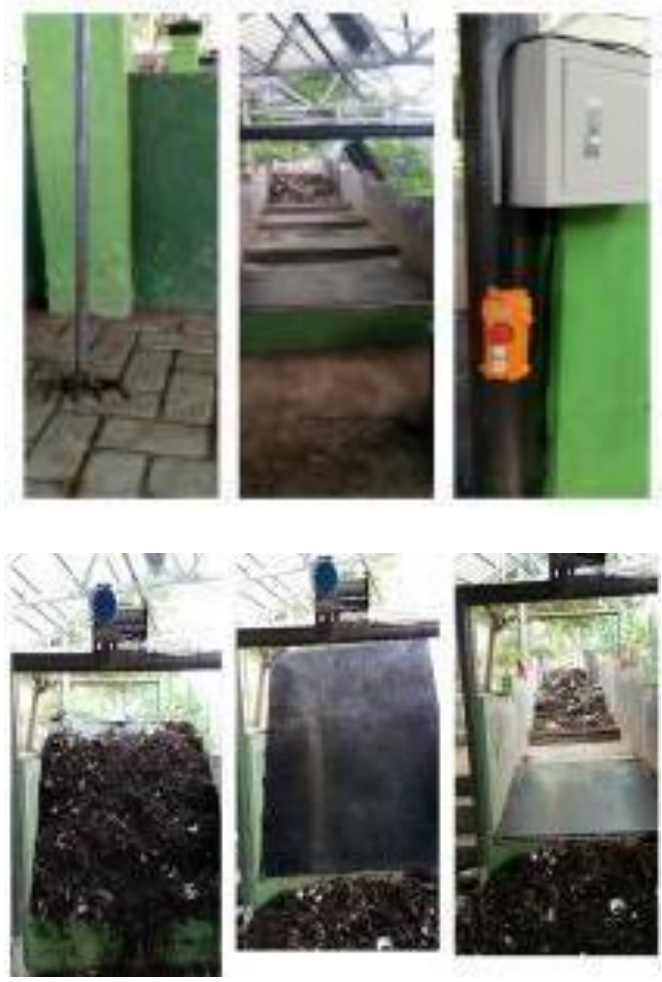

The weaknesses of the tools:

- There is a puddle of water on the garbage turning plate

- The size of the plate is too precise so that when it is pulled, it causes friction between the plate and the plate wall, this causes the waste reversal process to be imperfect.

- The process of turning waste in tub 1-9, the tool used and the process of turning the waste

appropriate and can support the waste composting process. The volume of waste in the basins 1 to 10 is on average around 0.5-4 $\mathrm{m} 3$ / week, in each tub per week there is a decrease in waste by an average of about $8-9 \%$, so starting from basin 1 turning plate over is not lifted to be reversed but what happens is that it is attracted, except in the 10 th tub the turning plate can be lifted to reverse.

\section{Discussion}

The test results of this tool get a design that meets the needs in waste processing, mainly waste reversal. Reversal of the waste pile as compost material aims to mix compost raw materials to make it more homogeneous and prevent clumping on the surface of the compost pile, so the composting process takes place faster. The reversal should be done by transferring the top layer to the middle layer, then the middle layer to the lower layer and the lower layer to the upper layer. Therefore, the turning process needs to be done at least 1 (one) week so that the compost mixture does not harden.

The results of the waste reversal process succeeded in reducing the amount of energy required from 4 people to 2 people, and allowing it to be carried out by 1 operational staff. Based on the time of reversal, there is a significant difference between reversing waste using a machine and reversing conventional waste, reversing conventional waste takes 5-7.5 minutes, while reversing waste using a waste turning tool only takes $45-50$ seconds. This shows that the ability of the tools has been effective in supporting the acceleration of the waste management process on campus 7 Poltekkes Kemenkes Semarang for compost.

The results of the first function test of the operation of the tool found that there were several problems, including the turning device that was supposed to function to turn the waste turning plate not functioning optimally in the 1st to 9 th basins, The raised plate to turn the trash over is only optimal on the 10 th tub.

In the second function test, the waste turning tool is functioning properly. Based on the results of measuring the weight of waste for each container, it is in the range of $285-350 \mathrm{~kg}$, so that a conventional reversal requires a lot of waste management personnel. The period of time for fast waste reversal, which is about $45-50$ seconds, can streamline the time and number of waste management personnel on campus 7 Poltekkes Semarang. Before using the trash turner, the total time needed to turn the trash from the 1 st to the 10th basin takes about 50 - 75 minutes or 3,000 - 4,500 seconds, whereas if you use a trash turner the time it takes to turn the trash from the basin to the -1 to the 10 th bath about $7.5-8.3$ minutes or 450 - 500 seconds, there is a time difference of the reversal process of about 66.7 minutes or 4,000 seconds. The short turning time and the least effort required will optimize the waste turning process, so that the quality of the resulting compost is maintained. The design and assembly of a waste turning tool is

with a volume of $4 \mathrm{~m} 3$ / week of waste decreases in the 10th basin to $0.5 \mathrm{~m} 3$ / week. Thus the tool is effective and able to solve the problem of reversing waste on campus 7 Poltekkes Kemenkes Semarang. Based on the analysis when testing the 173 
shortage of existing tools, further engineering can be planned such as:

- To remove stagnant water, the slab floor was perforated, so that water could flow downwards and help the compost drying process.

- To eliminate plate friction with the tub wall, the plates are cut $1 \mathrm{~cm}$ each on the right and left sides, so that friction does not occur, the turning process is smooth.

- For the reversal of the tub 1-9 sling / pulling wire is given a support so that the plate can be lifted to be turned over.

From the observations of the work of the tool, it is necessary to apply several work steps for the operation of the tool, including:

- Check engine condition

- Check the condition of the pulley strap

- Attach the pulley strap support

- Linking the pulley rope of the trash turning tool

- Start the trash turning machine If the machine is stuck, immediately turn off the machine,then check again.

\section{Conclusion}

The waste turning tool helps and facilitates the process of turning waste for the decomposition process in the composting basin at the composting site Campus 7 Poltekkes Kemenkes Semarang.

The waste turning tool is effective in supporting the composting process, with a waste turning time difference of 66.7 minutes when compared to the conventional / manual waste turning process.

Reversing manual waste takes about 5-7.5 minutes per repair with 4 workers, so it takes 5075 minutes to reverse 10 basins.

Turning waste with a machine takes about 4550 seconds with 2 workers, so it takes 7.5-8.3 minutes to reverse 10 basins of waste.

\section{Acknowledgment}

Many thanks are conveyed to Poltekkes Kemenkes Semarang

\section{Reference}

Anonim. Dasar dasar Sistem Pengelolaan Persampahan pplpdinciptakaru.jatengprov.go.id accessed January 2018.

Bandura, Albert. 1997. SELF-EFFICACY: The Exercise of Control. Stanford University. New York. W.H. Freeman and Company.

Creswell, J.W. 1994. Research Design Qualitative and Quantitative Approaches. Sage Publication : London.

Creswell, J.W and Dana L Miller. 2000. Determining Validity in Qualitative
Inquiry. Theory Into Practice Vol. 39, No. 3, Getting Good Qualitative Data to Improve Educational Practice (Summer, 2000), pp. 124-130.

Enri Damanhuri dan Tri Padmi. 2010. Diktat Pengelolaan Sampah. ITB : Bandung.

Hill, Tosi., Caroll, SJ. 1997. Organizational Theory and management : A Macro Approach. John Willey and Sons Inc : New York.

Jenna R.Jambeck, Roland Geyer, Chris Wilcox, Theodore R.Sieger, Miriam Perryman, Anthony Andrady, Ramani Narayan, Kara Lavender Law. 2015. Plastic waste inputs from land into the ocean. Sciencemag 13 February 2015 Vol 374 Issue 6223.

Okut Ookumu, J. And Nyenje, R. 2011. Municipal Solid Waste Management Under Decentralization in Uganda. Habitat International Volume 35, Issue 4 , October 2011, Pages 537-543.

Peraturan Pemerintah Republik Indonesia, nomor 17 Tahun 2010, tentang Pengelolaan dan Penyelenggaraan Pendidikan. Jakarta.

Pemerintah Kota Yogyakarta, 2014, Profil Kota Yogyakarta, Yogyakarta : Pemkot Yogyakarta.

Siti Marwati. 2013. Pengelolaan Sampah Mandiri Berbasis Masyarakat. Jurusan Pendidikan Kimia FMIPA UNY.

Slamet Santoso SP. 2010. Dampak Negatif Sampah Terhadap Lingkungan dan Upaya Mengatasinya. Fakultas Biologi UNSOED.

Tobing, I. S. (2005). Dampak Sampah Terhadap Kesehatan Lingkungan dan Manusia. Jakarta: Fakultas Biologi Universitas Nasional, 1-9.

Undang-Undang Nomor 18 Tahun 2008 Tentang Pengelolaan Sampah.

Willie Susuki, Air Handono Ramelan dan Dwi Aries Himawanto. 2016. Penanganan Sampah Berdasarkan Karakteristik Sampah di Kota Surakarta. FKIP UNS.

Yin, R. 1994. Case Studi research : Design and methods (2nd ed). Sage Publications, Thousand Oaks, CA 


\section{BULETIN GMAS}

Terteif pertama kali April 1982 Buletin Kesehatan Lingkungan Masyarakat 